\title{
Rus Kaynaklarına Göre Lozan Konferansı'nda Boğazlar Meselesi
}

\section{The Straits Question at The Lausanne Conference}

\author{
Nigâr MAHARRAMOVA CENGİZ ${ }^{1}$ (1)
}

'Doktora Öğrencisi, İstanbul Üniversitesi, Atatürk IIlkeleri ve İnkılâp Tarihi Enstitüsü, İstanbul, Türkiye

\section{ORCID: N.M.C. 0000-0001-9346-1487}

Sorumlu yazar/Corresponding author: Nigâr Maharramova Cengiz,

İstanbul, Türkiye

E-posta/E-mail:

nigar.cengiz@ogr.sakarya.edu.tr

Başvuru/Submitted: 08.10.2019 Revizyon Talebi/Revision Requested: 29.11.2019

Son Revizyon/Last Revision Received: 10.12.2019

Kabul/Accepted: 25.12 .2019

Atıf/Citation: Maharramova Cengiz, N. (2019). Rus kaynaklarına göre lozan konferansı'nda boğazlar meselesi. Yakın Dönem Türkiye Araştırmaları-Recent Period Turkish Studies, 36: 179-198. https://doi.org/10.26650/YTA2019-673232

\section{ÖZ}

Marmara Denizi, İstanbul ve Çanakkale Boğazı'ndan oluşan Boğazlar Bölgesi, tarih boyunca ekonomik, politik, askeri yönden büyük devletlerin dikkatini çekmiştir. Osmanlı Devleti'nin arazisini ele geçirmeye yönelik emperyalist müdahalenin başarısızlığı ile sonuçlanan Kurtuluş Savaşı sonrasında, Türkiye Cumhuriyeti Devleti'nin yasal sınırlarını onaylamak, yeni bir Yakın Doğu tesis etmek üzere Lozan Konferansı toplanmıştır. Boğazları kontrolünde tutan devletlerle, bu deniz yolundan yararlanmak isteyen devletlerin arasındaki sorunlar ve bu sorunların çözümüne ilişkin çalışmalar, konferansta Boğazlar Meselesi kapsamında tartışılmıştır. Lozan Konferansı yeni Türk devletinin sınırlarının çizildiği bir sözleşme ile sonuçlanmış; antlaşmada Türkiye'nin bağımsız ve egemen bir devlet olduğu tasdik edilirken, Boğazlar konusundaki muamele bu düzenlemeye uygun olarak yapılmamıştır. Bu çalışmada Lozan Konferansı'nda tartışılan en önemli konulardan biri olan Boğazlar Sorununa değinilmiş, konferans süresinde ve ikili görüşmelerde yapılan konuşmalar, öne sürülen çözümler ile ilgili bilgi verilmiştir. Katılan devletlerin meseleye ilişkin siyasi manevraları, bu eylemlerin altında yatan sebepler araştırılmıştır. $\mathrm{Bu}$ çalışmanın amacı, Rus diplomatik kaynaklarına dayanarak Karadeniz ile Akdeniz çevresinin ve halklarının ekonomik, kültürel gelişiminde önemli rolü olan bu bölge üzerinde uluslararası ilişkilerin nedenlerini, koşullarını, özelliklerini ve sonuçlarını araştırmaktır. Ayrıca devletlerarası çatışmalar sırasında ve sonrasında ülkelerin konumlarını belirlemek, değerlendirmek, onlara nihai bir tanım vermek de bildirinin temel amaçları içerisinde yer almaktadır. Bu araştırma kapsamında Lozan Konferansı Tutanakları ve Lozan Antlaşması metni ana kaynak olarak incelenmiştir. Konferans tutanaklarının yanı sıra, önemli bulunan hatıratlara, telgraf ve anılara da yer verilmiştir. Lozan Konferansı'nda Boğazlar Meselesi 'ne taraf olan Sovyetler Birliği'nin yaklaşımı SSCB Dışişleri Komiserliği'nin belgeleri, notaları ve mektupları ele alınarak incelenmiştir. 
Türkiye Cumhuriyeti'nin konferanstaki baş delegesi İsmet İnönü'nün ve Ankara Hükümeti'nin boğazlar sorunu ile ilgili politik yaklaşımları incelenerek yorumlanmıştır. Boğazlar Meselesi'nin konferansa katılan tarafların hedefleri ve stratejik çıkarları açısından kapsamlı jeopolitik analizinin yapılması, bu deneyimin ışığında hangi rejimin yeni Türk devletinin çıkarlarına daha uygun olduğu gerçeğini ortaya çıkarmaya hizmet etmektedir.

Anahtar Kelimeler: Lozan Konferansı, Boğazlar Meselesi, Türkiye Cumhuriyeti, İsmet İnönü, Sovyetler Birliği

\section{ABSTRACT}

The Marmara Sea, Istanbul and the Straits of the Dardanelles have attracted the attention of great powers from the economic, political and military perspectives throughout history. After the war which resulted in the failure of the imperialist intervention to seize the land of the Ottoman State, the Lausanne Conference was convened to approve the legal limits of the Republic of Turkey and to establish a new Near East. The studies on the problems between the states that control the straits and the states that want to benefit from this sea route and the solutions of the problems have been discussed within the scope of the Straits Question at the conference. The Lausanne Conference concluded with a treaty which defines the lines of the new Turkish State. It has been acknowledged in the Treaty that Turkey is an independent and sovereign state, but the treatment on the Straits issue has not been made in accordance with this arrangement. In this study, one of the most important issues discussed in the Lausanne Conference- the question of the Straits was addressed, information was given about the solutions which were put forward, speeches made during the conference and bilateral talks. Political maneuvers related to the issues of the participating states have been searched for the reasons underlying these actions. The Straits question was interpreted by examining the political approaches of the main delegate of the conference, İsmet İnönü and the Government of Ankara. In the study, the document analysis method, which is one of the qualitative research methods, was used, and the resources of the period were examined. In addition to the reports of the conference, important memories, telegrams and memorials were also included. The approach of the Soviet Union, which is a party to the Straits question was examined at the Lausanne Conference by analyzing the documents, notations and letters of the Foreign Affairs Commissioner. The Lausanne Conference, which was the beginning of Turkey's legitimacy as a state on the international scene, still has an important place in the perception and interpretation of foreign policy.

Keywords: Lausanne Conference, the Straits Question, Republic of Turkey, İsmet İnönü, Soviet Union

\section{Giriş}

I. Dünya Savaşı sonrasında mağlup devletler zor koşullara sahip barış antlaşmaları imzalamaya mecbur edilmiş, dünya haritası yeniden şekillendirilmiştir. Bu devletlerden biri de Osmanlı İmparatorluğu'dur. Galip devletler, Osmanlı'nın geniş topraklarını paylaşma konusunda anlaşmakta zorlanırken, imzalanan Mondros Ateşkesi sonrasında, Anadolu ve Trakya'da başlayan İtilaf devletlerinin işgallerine karşı ilk önce yerel ölçekte Müdafaa-i Hukuk cemiyetleri tarafindan Millî Mücadele hareketi başlatılmış ve Sivas Kongresi'nden sonra bu hareket, Anadolu ve Rumeli Müdafaa-i Hukuk Cemiyeti ile Mustafa Kemal Paşa'nın başkanı olduğu Heyet-i Temsiliye'nin kurulmasıyla ulusal nitelik kazanmıştır. Bu mücadele, Türk ordusunun 30 Ağustos 1922'de Dumlupınar'da Yunan ordusuna karşı kazandığı zaferle taçlanmış ve 11 Ekim 1922 tarihinde imzalanan Mudanya Mütarekesi ile Anadolu'daki Türk-Yunan Savaş1 sona erdiği gibi, Yunan 
ordusunun Anadolu ve Doğu Trakya'dan tahliyesi gerçekleşmiştir. Bu askeri zafer, Mustafa Kemal Paşa ile TBMM'nin ve onun hükümetinin başarısıdır. İtilaf Devletleri, Ankara Hükümeti'ni barış esaslarını görüşmek üzere Lozan'da toplanacak konferansa davet etmiş; 13 Kasım' da düzenlenmesi planlanan konferans ${ }^{1}, 20$ Kasım 1922- 4 Şubat 1923 ve 23 Nisan-24 Temmuz 1923 tarihleri arasında iki aşamalı yapılmıştır. Sevr Antlaşması'nın onaylanmamasından dolayı uygulatma imkânı bulamayan İtilaf Devletleri'nin amac1, tarihi "Doğu Sorunu” çerçevesinde, Sevr Antlaşması hükümlerini hafifletmek suretiyle Türklere kabul ettirmekti. Lozan Konferansı'nı “Doğu Sorunu”nun nihai eylemi² olarak tanımlarsak tarafların beklentilerini ve siyasi durumu daha iyi anlayabiliriz. İsmet Paşa'nın deyimi ile konferans aslında Osmanlı İmparatorluğu'nu tasfiye etmek $^{3}$, başka bir tabirle mirasını paylaşmak için tertip edilmiştir. Tartışmalı konuların arasında kapitülasyonlar, Boğazların durumu, Düyun-u Umumiye, Musul, adalar ve azınlıklar meselesi vardır. En önemli ve çözülmesi icap eden meselelerden biri de Boğazlar sorunudur.

İstanbul Boğazı, Marmara Denizi ve Çanakkale Boğazı'ndan meydana gelmekte olan Boğazlar bölgesi, tarih boyunca ekonomik, politik, askeri yönden büyük ve güçlü devletlerin dikkatini çekmiştir. Osmanlı Devleti ilk defa 1774 Küçük Kaynarca Antlaşması ile Rus ticaret gemilerinin Boğazlardan serbestçe geçmesini ve hatta her iki ülkeye ait denizlerde adı geçen tarafların ticaret gemilerinin serbestçe dolaşmasını (Madde 11) kabul etmişti. ${ }^{4}$ Buna karşılık İngiltere, 1790'dan itibaren Osmanlı Devleti'nin topraklarının korunmasını amaçlayan bir dış politika izlemeye başlamıştı. Bu politikanın tercih edilmesinde Çarlık Rusyası'nın Boğazları kullanarak güneye, s1cak denizlere inme siyaseti en temel faktördü. Her ne kadar 1833 tarihli Hünkar İskelesi Antlaşması ile Rusya, Osmanlı Devleti ve Boğazlar üzerinde himaye elde etmişse de bu durum uzun sürmemişti. Sonunda Mısır'da ortaya çıkan Mehmet Ali Paşa meselesinin çözümünden (15 Temmuz 1840) sonra, Osmanlı Devleti, Avusturya, Prusya, Fransa, Rusya ve İngiltere Boğazlar Meselesi'ni görüşmek üzere Londra'da toplanmış ve 13 Temmuz 1841'de imzalanan Londra Sözleşmesi ile eskiden olduğu gibi barışta Boğazların kapalılı̆̆ı ilkesini kabul etmişlerdi. Buna göre, barış dönemlerinde hiçbir

1 Tam adı - Yakın Doğu Sorunları üzerine Lozan Konferansı.

2 Хормач Ирина Александровна, Советская Россия на Лозаннской Конференции по Урегулированию Положения на Ближнем Востоке (1922-1923 Годы), Новая и Новейшая История, 2019, №2, С. 74-92, с. 74. [Khormach Irina Aleksandrovna, Sovetskaya Rossiya na Lozanskoy Konferentsii po Uregulirovaniyu Polojeniya na Blijnem Vostoke (1922-1923 God1), Novaya i Noveyshaya İstoriya, 2019, 2, s. 74-92, s. 74]

3 Seha Meray, Lozan Barış Konferansı Tutanaklar Belgeler (LBK),I/1-1, Ankara Üniversitesi Basımevi, İstanbul, 1969 , s. V (İsmet Paşa'nın önsözü).

4 Nihat Erim, Devletlerarası Hukuku ve Siyasi Tarih Metinleri I, Ankara, 1953, s. 125-126. 
savaş gemisi boğazlardan geçemeyecekti ${ }^{5}$. Böylece Boğazlar, bir uluslararası garanti statüsüne kavuşmuştu. Söz konusu statü, 30 Mart 1856 yılında imzalanan Paris Barış Antlaşması'yla teyit edildiği gibi ${ }^{6}, 13$ Temmuz 1878 tarihli Berlin Antlaşması'nda da aynı hükümler korunmuştur ${ }^{7}$.

Ancak, I. Dünya Savaşı'na gelindiğinde; İngiltere ve Fransa'nın Sykes-Picot gizli antlaşması çerçevesinde “onay payı” için Boğazlar konusunda Rusya ile anlaştığını görmekteyiz. Bu durum, Ekim 1917 tarihli Bolşevik İhtilali ile Rusya’nın savaştan çekilmesiyle değişmiş ve savaş sonu imzalanan 30 Ekim 1918 tarihli Mondros Mütarekesi ile de İngiltere ve Fransa'nın ortak ilgisine mazhar olmuştur. Sonunda, 13 Kasım 1918 'de fiilen ve 16 Mart 1920'de ise resmen İstanbul ve Boğazlar bölgesi İtilaf Devletleri tarafından işgal edilmiştir. Nitekim işgal şartlarında imzalanan 10 Temmuz 1920 tarihli Sevr Antlaşması ile Osmanlı Devleti, Boğazların savaşta ve barışta tüm ülkelerin savaş ve ticaret gemilerine açık olmasını ve Boğazlar ile ilgili düzenlemelerin Uluslararası Boğazlar Komisyonu tarafindan yapılmasını kabul etmiştir. ${ }^{8}$

"Yakındoğu İşleri Hakkında Lozan Konferansı" başladığında Boğazlar Meselesi'nde durum buydu. Söz konusu mesele, konferansta 4 Aralık 1922’ de, Arazi Komisyonu Başkanı olan İngiliz Dışişleri Bakanı Lord Curzon’un “tüm dünyayı ilgilendiren bir sorun" olduğunu sözleriyle tartışmaya açılmıştır. ${ }^{9}$ Bu konu Curzon’un deyimi ile tüm dünyayı -özellikle Sovyetler Birliği'ni- yakından ilgilendiriyordu. Daha önce Cenova Konferansı'na davet edilen Rusya Sovyet Federatif Sosyalist Cumhuriyeti (RSFSC) Hükümeti, Türkiye'nin bu konferansa katılması için çaba harcamış, fakat girişimleri sonuçsuz kalmış, Boğazlar sorununun görüşülmesi Lozan Konferansı'na ertelenmiştir. ${ }^{10} \mathrm{Bu}$ sefer RSFSC Hükümeti konferansa resmen davet edilmemiştir. Sovyet Rusya, kendisi için hayati öneme sahip olan konu ile ilgili 30 Eylül 1922 tarihli notasında "İngiliz Hükümeti'nin ayrıca savaştan zaferle çıkmış devletlerin Boğazlarda, Rusya ve bağlaşıklarının çıkarlarını çiğneyen bir rejimi kurmalarını protesto ettiğini” belirtmiş, "Büyük Britanya makamlarının başkalarının denizlerinde ve topraklarındaki bu keyfi ve sorumsuz davranışını ancak, Karadeniz

\footnotetext{
Nihat Erim, Devletlerarası Hukuku..., s. 312-313.

Nihat Erim, Devletlerarası Hukuku..., s. 346-347.

Nihat Erim, Devletlerarası Hukuku..., s. 423.

Nihat Erim, Devletlerarası Hukuku..., s. 544.

Seha Meray, $L B K, \mathrm{I} / 1-1$, s. 129.

10 Stefanos Yerasimos, Kurtuluşs Savaşı’nda Türk-Sovyet İlişkileri (1917 -1923), İstanbul, Boyut Yayıncılık, 2000, s. 335.
} 
devletlerinin çıkarlarına karşı en ufak bir saygı duymadığ Bunun yanında 27 Kasım 1922'de Rusya, Ukrayna ve Gürcistan delege heyetinin Lozan Konferansı'na gönderdiği notada “Rusya ve müttefiklerinin sadece bu konuda değil tüm tartışmalı konularda müzakerelere katılması ve görüşlerini beyan etmesinin doğru olacağını, aksi takdirde Rusya’nın haberi olmadan alınan tüm kararların geçersiz kabul edileceği'" ${ }^{12}$ beyan edilmiş, Sovyet Rusya'nın konferansa katılma talebi karŞ1 tarafa iletilmiştir. Bu notanın karşılıksız kaldığını ve Rusya, Ukrayna ve Gürcistan delege heyetinin sadece Boğazlar Meselesi'ni konuşmak için konferansa katılma kararı almaya mecbur kaldıklarını 3 Aralık 1922 tarihli nota ile görmekteyiz. Notada "güçlü devletlerin zayıfların hakkını yemesini engellemek için konferansa katılmaya karar verildiği”" açıklanmaktadır. ${ }^{13}$ Sovyet delegasyonu başkanı Chicherin, Sovyetler Birliği liderleri ile bir araya gelerek Lozan Konferansı'nda sunacakları projeyi hazırlamıştır. ${ }^{14}$ Politburo'nun kararı ile konferansta Sovyet Rusya’nın Boğazlar konusundaki görüşünü geliştirmek için Lev Trotsky ${ }^{15}$, Karl Radek ${ }^{16}$ ve G. Chicherin'den oluşan komisyon kurulmuştur. Ana noktaları ile bir fikir birliğine varan komisyonun adından G. Chicherin, 17 Ekim 1922'de Josef Stalin'e bir mektup göndererek Sovyet Rusya'nın Boğazlar konusundaki tezini açıklamış ve onay istemiştir. ${ }^{17} \mathrm{Bu}$ detay, Boğazlar konusunun Rusya önemini gözler önüne sermektedir.

I. Dünya Savaşı ve Bolşevik Devrimi ile birlikte Rusya Boğazlar politikası da değiştirmiştir. 19.'yy. da Rus devleti sıcak denizlere inmek için boğazların açık tutulması politikasını desteklerken, İngilizler tam tersini -boğazların kapalı kalması gerektiğini- savunmaktaydılar. Bu değişimin Rusya açısından en önemli sebebi, Rus filolarının Karadeniz'de yapılan iç savaşta tamamen tahrip edilmesiydi. Böylece İngiliz filolarını

11 Документы Внешней Политики 5, Документ 270, Москва, Государственное Издательство Политической Литературы, 1961, с. 604 [Dokumentı Vnesney Politiki 5, Dokument 270, Moskva, Gosudarstvennoe İzdatelstvo Politicheskoy Literaturı, 1961, s. 604.]

12 Документы Внешней Политики 6, Документ 10, Москва, Государственное Издательство Политической Литературы, 1962, с. 20. [Dokumentı Vnesney Politiki 6, Dokument 10, Moskva, Gosudarstvennoe İzdatelstvo Politicheskoy Literaturı, 1962, s. 20]

13 Документы Внешней Политики 6, Документ 15, Москва, Государственное Издательство Политической Литературы, 1962. [Dokumentı Vnesney Politiki 6, Dokument 15, Moskva, Gosudarstvennoe İzdatelstvo Politicheskoy Literatur1, 1962]

14 Чичерин Георгий В, Ленин и внешняя политика, 30 Январ, Известия, 1924.[Chicherin Georgiy V., Lenin i Vneshnyaya Politika, 30 Yanvar, İzvestiya, 1924]

15 Lev Trotsky - Bolşevik siyasetçi, devrimci ve Marksist teorisyen.

16 Karl Bernhardoviç Radek- Sovyet siyaset adamı ve gazeteci.

17 Нежинский Л.Н., Игнатьев А.В. (ред.) Россия и Черноморские проливы (ХVIII-XX столетия), Международные отношения, Москва, 1999, s. 365.[Nejinskiy L.N, İgnatyev A.V. (red) Rossiya i Chernomorskiye Prolivı (XVIII-XX stoletiya), Mejdunarodniye Otnasheniya, Moskva, 1999, s.365.] 
Karadeniz'den uzak tutmak konusunda endişe duyan Ruslar, kendi donanmalarının Akdeniz'e inmesiyle artı ilgilenmiyorlard $1 .{ }^{18}$

Konferans sadece katılan devletleri değil dünya gündemini meşgul etmektedir. Dönemin dünya basını konferansla yakından ilgilenmiştir. Batı basını için yazdığı yazıda Ernest Hemingway ${ }^{19}$, İngiliz İmparatorluğu ve gelecekteki Rus İmparatorluğu arasındaki bu günlük umutsuz mücadelede, Curzon'u İngiliz filosunu selamlayan buz sarkitı gibi uzun soğuk adam, Chicherin'i ise tarihten örnekler getirerek, istatiksel verileri, tutkulu itirazlarıyla tehlikeleri savuşturarak, sonunda bütün bunların yararsız olduğunu görerek düşüncelerini gelecek nesillerin anlayışına devreden bir politikacı olarak tanımlamış ve Lozan Konferansı'nı ilginç kılan şeyin işte bu rekabet olduğunu belirtmiştir. ${ }^{20}$ 27.10.1922 y1lında, Observer ve Manchester Gardian gazetelerinden M. Farbman'a verdiği röportajında, Komünist Partisi Lideri Vladimir Lenin Boğazlar konusunda temel prensiplerinin öncelikle Türkiye'nin ulusal hedeflerinin memnuniyeti olduğunu ileri sürmüştür. ${ }^{21}$

3 Aralık 1922'de Amerikan gazetesi “Chicago Tribune”nün muhabiri ile görüşme esnasında Türk temsilcisi İsmet Paşa adına bir açıklama yapmış; Türklerin Boğazlar ile ilgili oturumlara neredeyse gözlemci olarak katılacaklarını, asıl aktif faaliyetin Ruslar tarafından yürütüleceğini açıklamıştır. ${ }^{22}$ Boğazlar konusunda İngiltere'nin izlediği politika, Kurtuluş Savaşı'nda yakın müttefik olan Sovyetler Birliği ile Türkiye'nin dostluk ilişkilerini engellemeye çalışmaktır. İngiliz yönetimi RSFSC yönetimini Türkiye ve Boğazlar konusunda samimi bulmamış, bu devletin asıl amacının ilk olarak İstanbul'un İngiliz yetkisi altına girerek ikinci bir Cebelitarık olmasını önlemek ve Boğazların gelecekte Cemiyet-i Akvam'ın yani Batı Avrupa'nın denetimi altında olmasına karşı çıkmak olduğunu belirtmişti. İngiliz Dışişleri yetkilisi Reginald W.A. Leeper'e göre; Rusya'nın asıl siyaseti kendisi zayıf olduğu sürece Boğazların Türk denetimi altında olmasını sağlamaktır. ${ }^{23}$ Sovyet tarihçisi İsaak Mints'e göre ise; Curzon’un dört ana hedefi vardı:

18 William Hale, Türk Dış Politikası 1774-2000, Çev. Petek Demir, Mozaik, İstanbul, 2003, s. 46.

19 Ernest Miller Hemingway, Amerikalı romancı, hikâye yazarı ve gazeteci.

20 Ernest, Hemingway, By Line: Ernest Hemingway; Selected Articles and Dispatches of Four Decades. Edited by William White, New York, Charles Scribner's, 1967, s. 66-68.

21 Ленин, Полное Собрание Сочинений 45, (Март 1922- Март 1923), Москва, Издательство Политической Литературы, 1970, s. 267. [Lenin, Polnoye Sobraniye Sochineniy, 45, (Mart 1922- Mart 1923), Moskva, İzdatelstvo Politicheskoy Literaturı, 1970, s.257]

22 Потемкин В.П, История дипломатии Том ІІІ Дипломатия в Период Подготовки Второй Мировой Войны 19191939 г2, ОГИЗ, Государственное Издательство Политической Литературы, Москва, 1945, s. 216.[Potemkin, V.P., Istoriya Diplomatii, Tom III, Diplomatiya v Period Podgotovki Vtoroy Mirovoy Voynı, 1919-1939 gg., OGİ, Gosudarstvennoe İzdatelstvo Politicheskoy Literatur1, Moskva, 1945, s.216]

23 Salahi Sonyel, Gizli Belgelerle Lozan Konferansının Perde Arkası, Ankara, Türk Tarih Kurumu Yayınları, 2014 , s. 23. 
1921 yılında imzalanan Moskova Antlaşması'nın Boğazlarla ilgili kısmını geçersiz kılmak, Sovyet Rusya'yı her an İngiliz filosunun Karadeniz'e gireceği korkusu ile tehdit etmek, Türkiye'deki Fransız etkisinin üstesinden gelmek ve ülkeyi sadece İngiliz himayesine zorlamak, nihai olarak Musul Meselesi’ni İngiltere lehine çözmek. ${ }^{24}$

Türkiye, bu düşman bloklar arasında sıkışıp kalma tehlikesi ile karşı karşıya olmasına rağmen, Batılı güçlere karşı Rus kartını oynamaya çalışmıştır. Bu talebi, sadece antlaşmalarla yüklendiği bir görevi yerine getirmek için değil, Boğazlar konusu görüşülürken bu devletlerin bulunmaması halinde alınacak kararların kalıcı olabileceğine samimi şekilde inanmadığı için yapmaktaydı. ${ }^{25}$ Boğazlar konusunda Sovyet Rusya yönetimi, Türkiye ile aynı tarafta olduğunu düşünmüş; 9 Kasım'da Sovyet Rusya Dışişleri Halk Komiseri Chicherin'in, Semyon Aralov ${ }^{26}$ aracılığıyla Mustafa Kemal ve Başbakan Rauf Orbay'a gönderdiği mesajda onlara Batılı devletlerce aldatılmamaları konusunda uyarıda bulunmuştur. ${ }^{27}$ İsmet Paşa, ilk temaslar sırasında Lord Curzon'a "Ruslarla yakın münasebetlerde olduğunu" belirtmiş, böylece siyasi bir manevra yaparak, aslında İtilaf grubuna karşı yalnız olmadıklarını dile getirmiştir. ${ }^{28}$ Paşa, 2 Aralık 1922 tarihinde Heyet-i Vekile Riyaseti'ne çektiği telgrafta; Türkiye'nin Boğazları sefain-i harbiyeye (harp gemilerine) açık olmasını kabul ettiği takdirde bunun Damat Ferit politikasının tekrarı olacağı konusunda Chicherin'in beyanlarını aktarmaktadır. ${ }^{29}$ Türk temsilci heyeti Lozan'a gelen Sovyet delege heyetinin Boğazların savaş esnasında kapalı tutulması ile ilgili tasarısından daha önceden haberdar olarak ${ }^{30}$, ikili görüşmelerde bu talepleri destekleyeceklerini belirtse de ${ }^{31}$ olaylar farklı şekilde gelişmiştir. H. Rakovsky ${ }^{32}$ tarafından Chicherin'e gönderilen raporda, Türk tarafının Lozan'da Boğazlar sorununun çözümüne ilişkin görüşlere ve somut önerilere ihtiyatlı, çekimser bir tutum sergilediği yazmaktadır. Bu durumu “Asıl mesele, Boğazlar hakkında Türkiye’den kararsız bir destek

24 Потемкин В.П. (ред.) История дипломатии Том III Дипломатия в период подготовки Второй мировой войны 1919- 1939 г2, ОГИЗ, Государственное Издательство Политической Литературы, Москва, 1945, s. 210. [Potemkin, V.P., Istoriya Diplomatii, Tom III, Diplomatiya v Period Podgotovki Vtoroy Mirovoy Voynı, 1919-1939 gg., OGIZ, Gosudarstvennoe İzdatelstvo Politicheskoy Literaturı, Moskva, 1945, s. 210]

26 Semyon İvanoviç Aralov- Sovyet asker, devlet adamı ve devrimci.

27 Aralov- Rauf görüşmesi, 9.11.1922- İnönü II, s.47-48; Shaw IV, s. 1881. Aktaran: Salahi Sonyel, Gizli Belgelerle Lozan Konferansının Perde Arkası, Ankara, Türk Tarih Kurumu Yayınları, 2014, s. 24.

28 İsmet İnönü, İsmet İnönü'nün Hatıraları, Büyük Zaferden Sonra Mudanya Mütarekesi ve Lozan Antlaşması 1, İstanbul, Yenigün Haber Ajansı Basın ve Yayıncılık A.Ş, 1998, s. 105.

29 Bilal Şimşir, Lozan Telgraflarl, Ankara, Türk Tarih Kurumu Basımevi, 1990, s. 159.

30 Bilal Şimşir, Lozan Telgrafları...,s. 157.

31 Bilal Şimşir, Lozan Telgrafları...,s. 159.

32 Hristiyan Georgiyeviç Rakovskiy, Bulgar devrimci. Sovyetler Birliği’nde devlet adamı ve diplomat olarak önemli görevlerde bulunmuştur. Lozan Konferansı'nda Sovyet Rusya'yı temsil eden delegasyonun bir üyesidir. 
alacağız. Geri kalan her şey bize karşı olacak...” diye tanımlayan Rakovsky, konferansin genel durumunu ve beklentileri analiz etmektedir. ${ }^{33}$ Görüldüğü üzere; Sovyet Dışişleri, Boğazların açık kalmasını kendilerine yönelik batılı bir tehdit olarak algılamakta ve yeni kurulan Türk devletinin dış politikasını yönlendirmek eğilimi taşımaktadır. Lozan' daki Chicherin ve Curzon arasındaki çatışma, yüzyılın başında Britanya ve Rusya arasındaki gerginliğin bir yansımasıyd $1^{34}$.

İsmet Paşa, Boğazlar Meselesi'nin çözümünde Sovyet heyetinin bulunmasını talep etmiş, bunu konferansta dile getirmiştir. 4 Aralık 1922 Pazartesi günkü oturumunda, Lord Curzon'dan sonra söz alan Paşa, Türk Hükümeti'nin dört y1l önce Misak-1 Millî’de belirttiği görüşünü açıklamış; hilafetin bulunduğu yer, saltanatın başkenti ve Osmanlı Hükümeti'nin merkezi olan İstanbul şehriyle Marmara Denizi'nin güvenliği ve her türlü saldırıdan korunması ilkesi saklı olmak şartıyla konferans kararına uyacaklarını açıklamıştır. Bu kısa konuşma İngiliz delege heyeti başkanı Curzon'u memnun etmemiş, fakat İsmet Paşa konu ile ilgili fikirlerini sonra açıklayacağını belirtmiştir. Bilal Şimşir, Lozan Günlükleri eserinde İsmet Paşa'nın bu tutumunun ve suskunluğunun dış basında da dile getirildiğini yazmaktadır. ${ }^{35}$ Aynı oturumda söz alan Rus Dışişleri Halk Komiseri Chicherin, okuduğu bildiri metninde özetle Türkiye'nin kendi ülkesi ve suları üzerinde tam haklara sahip olmasının icap ettiğini, silahlanma hakkını saklı tutmakla beraber, Boğazların savaş ve barış zamanı tüm ülkelerin savaş gemilerine kapalı olması gerektiğini deklare etmektedir. Politikacıya göre emperyalist güçler tarafından Rus halkı zorla savaşa sürüklenmek istenmektedir. Ayrıca Sovyet Dışişleri Komiseri, olası bir savaşa hazır olduklarını şu sözlerle ifade etmektedir: "Atlılarımızın Pamir tepelerinde görünmüş olmasından ve karşınızda, 1895 de size Hind-i Kuş tepesini bırakan yart-bunak Çar'ın artık bulunmamasından, belki kaygıya düşmüşünüzdür. Fakat size teklif ettiğimiz savaş değil, bizimle, bir ara-duvart ilkesine ve Türkiye’nin özgürlüğüyle egemenliği ilkesine dayanan, barıştır. "36 Rus tezi gayet açıktı: Boğazların savaşta ve barışta tüm ticaret gemilerine açık, tüm savaş gemilerine kapalı olması gerektiğini savunuyorlardı.

33 Нежинский Л.Н., Игнатьев А.В. (ред.) Россия и Черноморские проливы (XVIII-XX столетия), Международные отношения, Москва,1999, s. 371. [Nejinskiy L.N., İgnatyev A.V., (red.), Rossiya i Chernomorskiye Prolivl (XVIII-XX stoletiya), Mejdunarodniye Otnasheniya, Moskva, 1999, s. 371.]

34 Timothi Edward O’Connor, Г. В. Чичерин и Советская Внешняя Политика 1918-1930 г2, Пер. с англ. Общ. ред. Ю. С. Борисова; Послесл. И. М.Труша, Москва, Прогресс, 1991, s. 174. [Timothi Edward O’Connor, G.V. Chicherin i Sovetskaya Vneshnyaya Politika 1918-1930 gg. Per. s. Ang. Red. Y. S. Borisova, Moskva, Progress, 1991, s. 174]

35 Bilal Şimşir, Lozan Günlüğ̈̈, Ankara, Bilgi Yayınevi, 2012, s. 248.

36 Народный Комиссариат По Иностранным Делам. Годовой, Отчёт В 1923 Год Ко ІІ Съезду Советов, Москва, 1924, s. 95. [Narodniy Komissariat Po Inostrannim Delam, Godovoy Otchet v 1923 god ko II Syezdu Sovetov, Moskva, 1924, s. 95] 
Misak-i Millî'den örnekler vererek tezini destekleyen Chicherin, Boğazların savaş esnasında açık olmasının Mondros sonrasında müttefiklerin işgallerine sebebiyet verdiğini vurgulamıştır. ${ }^{37}$ Romanya delegesi Ion Gheorghe Duca, Boğazların anahtarının tek bir devletin cebinde olmasına ve bu devletin istediği gibi açıp kapatabilecek bir durumda olmasına razı olmadıklarını söylemiştir. Bu konuşma Romanya'nın İtilaf Devletleri'nin yanında yer aldığını göstermektedir. Sovyet delegeleri, ilk toplantıda "Karadeniz ülkeleri ve katılımcıların geri kalanı" şeklinde adlandırdıkları iki grubun ortaya çıktığını düşünseler de ilk grubun sadece coğrafi konumla ilgili olduğunun anlaşılması uzun sürmedi. Konferans esnasında Romanya ve Bulgaristan'ın bağımsız bir fikre sahip olmadığı ortaya çıkmıştır. ${ }^{38}$ Ayrıca Romanya temsilcisi, Boğazların savaş ve barışta tüm gemilere açık olmasını ve Karadeniz'in silahsızlandırılmasını talep etmiştir. Bulgaristan delegesi Alexandre Stamboulisky, takdim ettiği bildiride Boğazların ticaret gemilerine hem savaş hem barış döneminde açık olması gerektiğini savunmuştur. Sovyet tarihçi B. A. Dranov, Rumen delegenin konuşmasının, İngiliz diplomasisinin bir koyun postu giymeye ve küçük Karadeniz ülkelerinin önerilerinin "ilgisiz savunucusunun" karakteristik olmayan rolünü üstlenmeye niyetli olduğu gerçeğini yansıttığını iddia etmektedir. ${ }^{39}$ Lord Curzon, Türkiye'nin çıkarlarını savunan bir programın Rusya tarafından öne sürmüş olmasının dikkat çekici olduğunu vurgulamış, Chicherin'in yanılarak rol değiştirdiğini ve İsmet Paşa'nın kalpağını giydiğini ifade etmiştir. Bu sözleri ile Sovyet delegelerini tamamen Türkiye'nin görüşlerini ifade etmekle suçlamıştır. Curzon, konferansın bu evresinde aslında Türk tezinin ne olduğunu tam olarak bilmemekle birlikte, s1k sık İsmet Paşa'ya konu ile ilgili açıklama yapması konusunda baskı yapmıştır. İngiliz Dışişleri Bakanı, Türkiye ve Sovyet Rusya arasındaki müttefikliğin boyutunu anlayarak politikasını ona göre şekillendirmek istemiş, İsmet Paşa'yı kendi tarafına çekmek için de çaba sarf etmiştir. Konunun tartışılmaya başladığı ilk günlerde İsmet Paşa, Sovyet tezine yakın düşündüklerini belirtince Curzon, Türk heyetinin başka bir görüşe sahip olup olmadığını ısrarla sormuş̧tur. İsmet Paşa'nın Türk heyetinin görüşlerini aktarmayı daha sonraya ertelediğini öğrenince ise "bunun konferansla alay etmek olduğunu" ${ }^{40}$ belirtmiştir.

37 Seha Meray, $L B K, \mathrm{I} / 1-1$, s. 113.

38 Хормач Ирина Александровна, Советская Россия на Лозаннской Конференции по Урегулированию Положения на Ближнем Востоке (1922-1923 Годы), Новая и Новейшая История, 2019, №2, С. 74-92, s. 81. [Khormach Irina Aleksandrovna, Sovetskaya Rossiya na Lozanskoy Konferentsii po Uregulirovaniyu Polojeniya na Blijnem Vostoke (1922-1923 God1), Novaya i Noveyshaya İstoriya, 2019, 2, s. 74-92, s. 81]

39 Дранов Борис Анисимович, Черноморские Проливы (Международно-Правовой Режим), Москва Юридическое Издательство Министерства Юстиции СССР, 1948, s. 188.[Dranov Boris Anisimovich, Chernomorskiye prolivi (Mejdunarodno- Provavoy Rejim), Moskva, Yuridicheskoye İzdatelstvo Ministerstva Yustitsii SSSR, 1948,s. 188]

40 Seha Meray, $L B K$, I/1-1 s. 138. 
Konferansa Boğazların gelecek rejimi hakkında verilen temel üç tez aşağıdaki gibidir:

1. Müttefiklerin teklifi: Geçiş serbestisi, askerlikten tecrit ve kontrol.

2. Rus formülü: Kesin Türk egemenliği, harp gemlerine ve askerî uçaklara kapalılık.

3. Türk tezi: Askerlikten tecrit ve kontrolden vazgeçilmek şartıyla İstanbul ve Marmara'nın güvenliği kaydına bağlı geçiş serbestisi.

Konferansın 6 Aralık 1922 Çarşamba günkü oturumda Curzon, Rus heyetinin konuşmasına detaylı bir cevap vermiş, konuşulanlara ilişkin görüşlerini açıklamıştır. Rusya'nın asıl amacının Türkiye'nin Boğazlarda bekçilik yapmasını sağlamak, daha sonra ise bu bölgeyi kendi denetimine almak olduğunu ifade etmiştir. Karadeniz'in bir Rus gölü hâline gelmesini istemediklerini söyleyen Curzon Rus tezine karşı İtilaf Devletleri’nin tekliflerini okumuştur.

$\mathrm{Bu}$ projeye göre;

1. Boğazlar Ticaret gemilerine savaş ve barışta açık olacaktır.

2. Barış zamanı savaş gemilerinin sayısı ve kalış süresinin kısıtlanması dışında geçişi serbest olacaktır.

3. Savaş zamanında Türkiye tarafsızsa geçiş serbest, Türkiye savaştaysa tarafsız gemilere geçiş serbest olacaktır.

4. Askerlikten arındırılma konusunda müttefik devletler, Çanakkale ve Karadeniz boğazlarının her iki kıyısının askerlikten arındırılmasını önermektedirler.

5. Boğazlardan geçişin düzenleme yetkisi gerekli teknik donanıma sahip Askeri Komisyona verilecektir. Bu komisyon Batılı devletlerden ve kıyı devletlerinden oluşacak, başkanı bir Türk olacaktır.

İngiliz tezi, Türkiye'nin Boğazlar üzerindeki egemenlik haklarını ciddi bir şekilde kısitlamaktaydı. Fransız delege Camille Barrère ve İtalyan temsilci Marki Garroni yaptıkları konuşmada Lord Curzon'un görüşüne katıldıklarını ifade etmişler, ABD temsilcisi Richard Child "bir ulusun kendine coğrafyanın verdiği bir ayrıcalıkla öteki ulusları bu haklarından yoksun bırakmağa gücünün olduğunu iddia etmemesi gerektiğini" ${ }^{41}$ ve silahsızlandırmanın önemini vurgulamıştır. Bu konuşmaya istinaden ABD temsilcisinin

41 Seha Meray, $L B K$ I/1-1, s. 149. 
Boğazlar konusunda İngilizlerle aynı tarafta olduğu açıkça görülmektedir. Chicherin, konuşmasında Boğazları açarak genel silahsızlanmasının imkânsız hale getirildiğini ve yapılmak istenenin Rusya'ya karşı bir sistem yaratmak olduğu izlenimi edindiğini öne sürmüştür. Ayrıca Curzon'un 1871 Londra Sözleşmesi'ne göre Türkiye’nin güvenliğini sağlamak için müttefiklerinin filolarını kabul etme hakkının bulunduğu tezine karşı Chicherin, 1841 Antlaşması'nı örnek vererek Osmanlı'nın müttefik filolarını davet etmesinin her iki durumda geçersiz olduğunu, çünkü "antlaşmaya katılan tüm tarafların savaşa girdiklerinde, aralarındaki muahedelerin sona erdiği" tezini öne sürmüştür. ${ }^{42} 8$ Aralık 1922'deki bir başka konuşmada, Sovyet delegasyonunun başkanı, emperyalist güçlerin "sahillerimizdeki ticari ilişkileri silahlı filolar eli ile yürütmedeki 1srarlı arzusunun” yalnızca yasaları güçle değiştirme isteğinin bir ifadesi olabileceğine dikkat çekmiştir. ${ }^{43}$ Boğazlar konusunda iki taraf arasında kalan Türkiye'nin durumu, her iki devlet tarafından kendi görüşlerinin Türk çıkarlarına daha uygun olduğu noktasına ikna edilmek istenmesi durumu idi. ${ }^{44} 8$ Aralık’ta Lord Curzon başkanlığındaki oturumda İsmet Paşa, Boğazlara ilişkin tarihi bilgi vermekle birlikte Türk görüşlerini de açıklamıştır. Bu tasarıya göre ticaret gemileri için savaş ve barışta tam bir serbesti öngörülmüş, Boğazların, İstanbul'un ve Marmara Denizi'nin güvenliğini denizden ve karadan gelecek bir baskına karşı koruyacak garantiler verilmesini istemiştir. Rus tarihçi B.A. Dranov'a göre Türk delegasyonu başkanının konuşması çok genel ve soyut tartışmaların ötesine geçmediğinden Sovyet delegasyonu aslında, Türkiye'nin çıkarlarının savunmasını üstlenmiştir. ${ }^{45}$

Boğazlar Komisyonu çalışmalarına, 14, 16 ve 18 Aralık tarihlerinde devam etmiş, Sovyet Rusya ve Türkiye müttefik projelerine karşı tasarılar ileri sürmüştür. Rusya, Boğazların kapalı kalması konusunda 1srar ederken, İsmet Paşa, bazı değişikliklerle İngiliz tezini kabul edeceğini beyan etmiştir. Sonuçta İsmet Paşa, 20 Aralık'ta yapılan Boğazlar Komisyonu toplantısında Boğazlardaki sınırlı tahkimattan vazgeçerek, bunu bir miktar daha içeriye doğru genişletmeyi, savaş gemilerinin sınırlamalarla Boğazlardan geçmesini öngören İtilaf projesini kabul etmiş, ${ }^{46} 1$ Şubat 1923 ’te Boğazlar Komisyonu

42 Годовой Отчет за 1923 г. НКИД ІІ Съезду Советов СССР, 1924, Москва, s. 17. [Godovoy Otchet za 1923 g. NKID II Syezdu Sovetov SSSR, 1924, Moskva, s. 17]

43 Годовой отчет за 1923 г. НКИД ІІ съезду Советов ССCР, 1924, Москва, s. 20. [Godovoy Otchet za 1923 g. NKİD II Syezdu Sovetov SSSR, 1924, Moskva, s.20]

44 Ali Naci Karacan, Lozan, İstanbul, Nokta Yayınları, 2007, s. 152.

45 Дранов Борис Анисимович, Черноморские Проливы (Международно-Правовой Режим), Москва Юридическое Издательство Министерства Юстиции СССР, 1948, s. 187.[ Dranov Boris Anisimovich, Chernomorskiye Prolivi (Mejdunarodno- Provavoy Rejim), Moskva, Yuridicheskoye İzdatelstvo Ministerstva Yustitsii SSSR, 1948,s. 187]

46 Mustafa Budak, İdealden Gerçeğe Misak-ı Millî’den Lozan'a Dış Politika, İstanbul, Küre Yayınları, 2002, s. 333. 
da Türk delegasyonu tarafından onaylanmıştır. Böylece Boğazlar sorunu konferans tarafından çözüme kavuşturulmuş olarak kabul edilmiştir. Dolayısıyla Türk temsilci heyetinin beklenenin aksine Boğazlar konusunda Sovyet tezini değil, müttefiklerin tezini desteklediği ortaya çıkmış, bu konu anlaşılır olmakla birlikte pek çok tartışmaya da sebep olmuştur. Chicherin'in ve Sovyetler Birliği’nin tüm baskılarına, Rus tasarısının Türkiye için daha uygun olarak görülmesine rağmen İsmet Paşa neden müttefikleri desteklemiştir? İlk olarak Boğazlar konusunda Misak-1 Millı̂’nin ilgili maddesinin İngiliz tasarısıyla benzerlik taşıdığını söyleyebiliriz. İkincisi İsmet Paşa, Lozan Antlaşması'nın anahtarının Curzon'da, dolayısıyla İngiltere'de olduğunu fark etmiş, bu devletle zorunlu olmadığı sürece çatışmaya girmemeyi planlamıştı. Üçüncü ve en önemli konu, Sovyetler Birliği her ne kadar Millî Mücadele sırasında Türkiye'nin en yakın müttefiki de olsa, bu devlete karşı temelde ciddi bir güvensizlik söz konusu idi. Zira Türk Devleti, kapalı Boğazlarda güçlü bir Rus donanması ile karşı karşıya gelmek istemiyordu. Güçlü bir politikacı olan Curzon'un İsmet Paşa'ya bu konudaki telkinleri de göz ardı edilemez. Her ne kadar Chicherin, yazılarında ve söylemlerinde Sovyet Rusya'nın Çarlık dönemi politikalarını desteklemediğini belirterek, Çarlık politikasıyla Sovyet Rusya'nın doğu politikası arasındaki temel farkın birincisinin amacının doğu ülkelerinin ekonomik ve siyasi gelişmesini geciktirmek, bağımsız gelişimini önlemek olduğunu, bunun aksine Sovyet Rusya'nın Doğu halklarının üretici güçlerinin terakkisine çok yönlü desteği sağladığ1 yönünde beyanlarında bulunsa $\mathrm{da}^{47}$ Boğazlar konusundaki müzakereler Rus ve Türk heyetlerini karşı karşıya getirmiştir. Ruslar, hayal kırıklıklarını 11 Ocak’ta Ankara'da Rauf Bey ile Aralov arasında gerçekleşen özel görüşmede ve Lozan'da Chicherin'in İsmet Paşa'yı Hindistan ile diğer ülkelerin Müslüman temsilcileri karşısında küçük düşürme girişimiyle ifade edeceklerdi. ${ }^{48}$ Rus temsilci heyeti, İsmet Paşa'yı her iki tarafı idare etmeye çalışmakla suçlamıştır. ${ }^{49}$ Sovyet Rusya, Türkiye'nin çıkarlarını savunduklarını ve bunu Türklerden daha iyi yaptıklarını iddia etmekle birlikte, Türkiye'yi taraf değiştirmekle itham etmiştir. Bunun üzerine Türk delegelerden Riza Nur, Rus delegasyonu ile görüşmüş; Sovyet Rusya'nın Avrupa devletlerine karşı çıkacak bir savaşta Türkiye'ye askeri ve maddi yardım yapamayacağına kanaat getirdiklerini ve bu sebeple sulh yapmak zorunda olduklarını ifade etmiştir. ${ }^{50}$ İsmet Paşa, Chicherin'e meselenin bir harp başlatacak kadar ciddi olduğunu özel görüşmelerinde

47 Чичерин, Георгий Васильевич, Статьи и Речи по Вопросам Международной Политики, Москва, Издательство Социально-Экономической Литературы, 1961, s. 240.[Chicherin Georgiy Vasilevich, Stati i Rechi po Voprosam Mejdunarodnoy Politiki, Moskva, İzdatelstvo Sotsialno-Ekonomicheskoy Literaturı, 1961, s. 240]

48 Sevtap Demirci, Belgelerle Lozan, İstanbul, Alfa Yayınları, 2015, s. 121.

49 Bilal Şimşir, Lozan Telgrafları I, Ankara, Türk Tarih Kurumu Basımevi, 1990, s. 185.

50 Şimşir, Lozan Telgrafları ..., s. 185.; Rıza Nur, Hayatım Hatıratım, C.3, İstanbul, Altındağ Yayınevi, 1967, s. 1025. 
anlatmıştır. ${ }^{51}$ Konu ile ilgili 10, 11 ve 12 Aralık tarihlerinde Sovyetler Birliği ile Türkiye arasında karşılıklı telgraflar çekilmiş, Türkiye'nin bu tutumu müttefiki olduğu devlet tarafından protesto edilmiştir. 12 Aralık 1922'de Rus heyeti bulundukları oturumu terk etmiş ve varılan sonucun kendi açılarından tatmin edici olmadığını açıklamıştır. ${ }^{52}$ Aynı gün Sovyet delege, Chicherin'in dişişlerine çektiği telgrafta, Boğazlar kapalı olmadan İstanbul'un güvenli bir yer olamayacağı, fakat yeni Türkiye'yi Anadolu'da kurmayı planlayan hükümet için bunun önemli olmadığı yazmaktadır. Chicherin'e göre Türkler, Boğazları nasıl kontrol edeceklerini bilmiyor ve bu problemi Rusya'nın çözmesi gerektiğine inanıyorlardı. ${ }^{53}$ Sovyet Rusya'nın bundan sonraki siyasi tutumu daha da ilginçtir. Bilindiği üzere bu devlet, Boğazlarla İlgili Lozan Konvansiyonu'nu imzalamış, fakat resmi olarak tanımamıştır. Politbüro’nun tüm üyelerinin bu karar üzerinde mutabık olmadıkları bilinmektedir. ${ }^{54}$ Hatta Sovyetler Birliği'nde Türk Hükümet'iyle İngiliz Hükümeti'nin bu konuda önceden anlaştığı gibi düşünceler de ortaya çıkmıştır ${ }^{55}$. Sovyet Hükümeti, antlaşmanın imzalanması için konferans başkanlığı tarafından gönderilen telgrafa, Türk halkının hakkının ihlal edildiği için antlaşmayı protesto ettiklerini, fakat barışı teşvik etmek için sözleşmeyi imzalamaya hazır oldukları cevabını vermiştir. $\mathrm{Bu}$ imza "sözleşmeyi uygulama deneyimi, Sovyet devletlerinin ticari çıkarlarını ve emniyetini yeterince güvence altına almazsa, antlaşmanın askıya alınması sorununun gündeme getirileceği” şartı ile atılmıştır. ${ }^{56}$ Fakat konu ile ilgili geniş araştırmalar yapan Cemil Bilsel'e göre; Batı ile antlaşmanın Türk- Rus dostluğuna halel verebilecek hiçbir mahiyeti olmadığına ve Türkiye'nin daima bu dostluğa sadık kalacağına, Sovyetler de inandıkları için, Sovyetler Birliği ile politik ilişkiler bozulmadan devam etmiş, dostluk

51 İsmet İnönü, İsmet İnönü’nün Hatıraları, Büyük Zaferden Sonra Mudanya Mütarekesi ve Lozan Antlaşması 1, İstanbul, Yenigün Haber Ajansı Basın ve Yayıncılık A.Ş, 1998, s. 109.

52 Документы Внешней Политики 6, Москва Государственное Издательство Политической Литературы, 1962, s. 66. [Dokumentı Vnesney Politiki 6, Moskva, Gosudarstvennoe İzdatelstvo Politicheskoy Literaturı, 1962, s. 66]

53 Документы Внешней Политики 6, Москва, Государственное Издательство Политической Литературы, 1962, с. 66-67.[Dokumentı Vnesney Politiki 6, Moskva, Gosudarstvennoe İzdatelstvo Politicheskoy Literaturı, 1962, s. 66-67]

54 Борков Александр Васильевич, Ильин Александр Владимирович, Черноморские Проливы и Советско-Турецкие Отношения в 1917-1923 гг, Известия ВУЗов. Поволжский регион. Гуманитарные науки, №3 (31), 2014 , s. 45. [Borkov Aleksandr Vasilevich, İlin Aleksandr Vladimirovich, Chernomorskiye Prolivı i Sovetsko-Turetskiye Otnaşeniye v 1917-1923 gg, İzvestiya VUZOV, Povoljskiy Region, Gumanitarniye Nauki, İstoriya, № 3 (31), Moskva, 2014, s. 45]

55 1923'te Komünist Partinin Azerbaycan'da düzenlediği 5. şurasındaki konuşmasında, M.İ. Kalinin'in Lozan Konferansında Boğazlar sorunu tartışmalarını şöyle nitelendirmiştir: "Bu sorunu biz Türk heyetinden daha kararlı ve daha güçlü bir şekilde savunduk. Belli ki Türk yönetiminin bu sorun hakkında Antant tarafiyla daha önceden birtakım antlaşmaları vardı" akt. Mihail Serafimoviç Meyer, Arşiv Belgeleri Işı̆̆ında Lozan Konferansı Sırasında Türk-Rus İlişkileri, (Turkish-Russian Relations During the Lausanne Conference With Archieve Documents), Çev: Fatih Yapıcı, Akademik Bakuş, Cilt: 3, Say1: 5, 2009, s. 252.

56 Годовой отчёт НКИД за 1923 г. ІІ съезду Советов СССР, 1, 1924, Москва, с. 32. [Godovoy Otchet NKID za 1923 g. II Syezdu Sovetov SSSR, 1,1924, Moskva, s. 32] 
münasebetlerimiz gelişmiş, yeni yeni antlaşmalar yapılmıştır. ${ }^{57}$ Sovyet tarihçisi F. G. Zuev'in görüşüne göre; Türkiye, Lozan'da Sovyet delegasyonu ile birlikte hareket etseydi elde ettikleri daha fazla olurdu. ${ }^{58}$ Diğer bir Sovyet tarihçisi Gasratyan'a göre ise; bazı imtiyazlara ve uzlaşma kararlarına rağmen, Lozan Antlaşması, antant devletlerini Türk Devleti’nin egemenliğini, toprak bütünlüğünü ve bağımsızlığını yasal olarak tanımaya zorlayan bir başarı, Türk halkı için büyük bir zaferdir. ${ }^{59}$

Boğazlar konusunda Sovyet Rusya ile değil, İngilizlerle birlikte hareket etmek yeni Türk Devleti'nin batıya yönelişinin bir işareti idi. Kurtuluş Savaşı politikasının yerini Batı yönlü bir politika almıştır. Türkiye'nin genel Batıcı eğiliminin yanı sıra, mevcut realpolitik İngiltere'ye yaklaşmayı gerektirmekteydi. $\mathrm{Bu}$ nedenle, Boğazlar Sözleşmesi'nin temeli, İngiltere'nin yaklaşımı oldu. ${ }^{60}$ Sovyet tarafının savaş gemilerinin Boğazlar yolu ile geçişini kolaylaştıracak bir hükmü antlaşmaya ekleme girişimi başarısızlıkla sonuçlandı. Görüldüğü üzere Türk Hükümeti, diğer ülkelerle ilişkileri ağırlaştırmak değil, güçlendirmek istiyordu. ${ }^{61}$ Boğazlarla ilgili Rus heyetinin tüm protestolarına rağmen sözleşme aşağıdaki ana esaslarla imzalanmıştır:

- Boğazlar askerden arındırılacak, bu bölgede Türk ordusu bulunmayacaktır.

- Boğazlarda gemi trafiği düzenlemek için Milletler Cemiyeti’ne bilgi vermek üzere uluslararası bir Boğazlar Komisyonu kurulacaktır

- Askersizleştirilen Boğazlarda Türkiye’nin güvenliğini Milletler Cemiyeti, İngiltere, Fransa, İtalya ve Japonya garanti edecektir.

57 Cemil Bilsel, "Sovyet Rusya-Türk Notaları Aydınlığında Türk Boğazları”, İstanbul Üniversitesi Hukuk Fakültesi Mecmuası, Cilt: 14, Say1: 1- 2, 1948, s. 6.

58 Зуев Федор Григорьевич (ред.) История Международных Отномений И Внешней Политики СССР (1870-1957 г2.), Москва, ВПШ при ЦК КПСС, 1957, s. 167.[Zuev Fedor Grigorevich (red), Istoriya Mejdunarodnıkh Otnasheniy i Vneshney Politiki SSSR(1870-1915 gg), Moskva,VPSH pri TSK KPSS, 1957,s. 167]

59 Манвел Арсенович Гасратян, Светлана Филипповна Орешкова, Юрий Аиютович Петросян, Очерки Истории Туриии, Главная Редакция Восточной Литературы Издательство “Наука”, Москва, 1983, s. 176.[Manvel Arsenovich Gastaryan, Svetlana Filippovna Oreshkova, Yurii Aiyutovich Petrosyan, Ocherki İstorii Turtsii, Glavnaya Redaksiya Vostochnoy Literaturi İzdatestvo Nauka, Moskva, 1983, s. 176]

60 Baskın Oran, Türk Dış Politikası Kurtuluş Savaşından Bugüne Olgular, Belgeler, Yorumlar, Cilt: 1(1919-1980), İstanbul, İletişim, 2009, s. 221.

61 Киреев Николай Григорьевич, История Туриии. ХХ век, Москва, Крафт+ ИВ РАН, 2007, 1c.84.[Kireev Nikolay Grigorevich, Istoriya Turtsii.XX vek, Moskva, Kraft+IV RAN, 2007, s. 184] 
Lozan Sözleşmesi "Boğazlar” terimi içinde toplanan Çanakkale, Marmara Denizi ve İstanbul Boğazı'nda, denizde ve havalarda, geçiş ve seyrüsefer serbestisi prensibini kabul etmiştir. ${ }^{62}$

\section{Sonuç}

Lozan Konferansı yeni Türk Devleti’nin sınırlarının çizildiği bir sözleşme ile sonuçlanmıştır. Batı emperyalizmine karşı yapılmış Kurtuluş Savaşı'nda, Türkiye'nin yanında yer alan Sovyet Rusya ile ittifak politikasının terk edilerek, Batı'ya yönelmesinin simgesi, Boğazlar Meselesi olmuştur. Millî Mücadele politikasının yerini batı yönlü bir politika almış, bu yolun İngiltere'den geçtiğini anlayan Türkiye, barış için İngilizlerle uzlaşmak zorunda olduğunu anlamıştır. Asırlardır süregelen batılılaşma politikası, Batılı devletlerle çatışarak gerçekleştirilemezdi. 1911 yılından itibaren savaşan bir devletin ekonomik olarak da savaşacak gücü kalmamış, barışa muhtaç hale gelmiştir. İngiltere için Boğazlar en az Musul kadar önemli idi. Lozan'da barış görüşmeleri olumsuz sonuçlanırsa başlayacak bir savaşta Sovyet Rusya, İsmet Paşa'ya teminat vermiyor, her ne kadar Rus tezi Türkiye'nin daha yanında gibi gözükse de Türk Devleti, Sovyetler Birliği’ne çok güvenmediğini sergiliyordu. Boğazlar üzerinde Rus projesinin uygulanması durumunda Türkiye, Karadeniz ve Boğazlar 'da güçlü bir Rus donanması ile karşı karşıya kalarak bu donanmayı Batılı bir güçle dengeleme imkânından mahrum kalacaktı. Nitekim 1 Şubat 1922 tarihli son oturumda sadece Türkiye değil, aynı durumdan rahatsız olan Bulgaristan ve Romanya da İngiliz tezine yakın fikirler beyan etmişlerdir. Boğazlar Meselesi, Lozan Antlaşması ile son şeklini almamış; 1933'de Londra'da yapılan silahsızlanma konferansından başlayan süreçte, 20 Temmuz 1936'da imzalanan Montrö Sözleşmesi ile değişmiş, Uluslararası Komisyon'un tüm hakları Türkiye’ye devredilmekle birlikte, askerden arındırılma hükmü de kaldırılmıştır.

\section{KAYNAKÇA}

Борьков, Александр В., Ильин, Александр В.: Черноморские проливы и Советско- Турецкие отношения в 1917-1923 гг., Москва, Гуманитарные науки, История, 2014, 3 (31). [Borkov Aleksandr Vasilevich, İlin Aleksandr Vladimirovich, Chernomorskiye Proliv1 i SovetskoTuretskiye Otnaşeniye v 1917-1923 gg, İzvestiya VUZOV, Povoljskiy Region, Gumanitarniye Nauki, Istoriya, Moskva, 2014, 3 (31)]

62 Feridun Cemal Erkin, Türk- Sovyet İlişkileri ve Boğazlar Meselesi, Ankara, Başnur Matbaası, 1968, s. 57. 
Bilsel, Cemil:

Budak, Mustafa.:

Чичерин, Георгий В.:

Чичерин, Георгий В.:
"Sovyet Rusya-Türk Notaları Aydınlı̆̆ında Türk Boğazları", İstanbul Üniversitesi Hukuk Fakültesi Mecmuası, Cilt: 14, Sayı: 1- 2, İstanbul, 1948, ss. 1-23.

İdealden Gerçeğe Misak-ı Milli'den Lozan 'a, Dış Politika, İstanbul, Küre Yayınları, 2002.

Ленин и внешняя политика, 30 Январ, Известия, 1924. [Chicherin Georgiy V., Lenin i Vneshnyaya Politika, 30 Yanvar, İzvestiya, 1924]

Статьи и Речи по Вопросам Международной Политики, Москва, Издательство СоциальноЭкономической Литературы, 1961. .[Chicherin Georgiy Vasilevich, Stati i Rechi po Voprosam Mejdunarodnoy Politiki, Moskva, İzdatelstvo Sotsialno-Ekonomicheskoy Literatur1, 1961]

Demirci, Sevtap:

Belgelerle Lozan, İstanbul, Alfa Yayınları, 2015.

Документы Внешней Политики 5, Москва, Государственное Издательство Политической Литературы, 1961.[Dokument1 Vnesney Politiki 5, Moskva, Gosudarstvennoe İzdatelstvo Politicheskoy Literaturı, 1961]

Документы Внешней Политики 6, Москва, Государственное Издательство Политической Литературы, 1962.[ Dokumentı Vnesney Politiki 6, Moskva, Gosudarstvennoe İzdatelstvo Politicheskoy Literaturı,1962]

Дранов, Борис А.:

Черноморские проливы (международно-правовой режим), Москва, Юридическое Издательство Министерства Юстиции СССР, 1948.[Dranov Boris Anisimovich, Chernomorskiye Prolivi (MejdunarodnoProvavoy Rejim), Moskva, Yuridicheskoye İzdatelstvo Ministerstva Yustitsii SSSR, 1948] 
Хормач, Ирина А.:

Feridun, Cemal E.:
Советская Россия на Лозаннской Конференции по Урегулированию Положения на Ближнем Востоке (1922-1923 Годы), Новая и Новейшая История, №2, 2019. [Khormach Irina Aleksandrovna, Sovetskaya Rossiya na Lozanskoy Konferentsii po Uregulirovaniyu Polojeniya na Blijnem Vostoke (1922-1923 God1), Novaya i Noveyshaya İstoriya, 2019,2]

Türk- Sovyet İlişkileri ve Boğazlar Meselesi, Ankara, Başnur Matbaası, 1968.

Гасратян, Манвел А, Орешкова, Светлана Ф, Петросян, Юрий А.: Очерки Истории Турциии, Москва, Главная Редакция Восточной Литературы Издательство “Наука”, 1983.[Manvel Arsenovich Gastaryan, Svetlana Filippovna Oreshkova, Yurii Aiyutovich Petrosyan, Ocherki Istorii Turtsii, Glavnaya Redaksiya Vostochnoy Literaturi İzdatestvo Nauka, Moskva, 1983]

Gürün, Kamuran:

Türk Sovyet Ilişskileri (1920-1953), Ankara, Türk Tarih Kurumu, 2010.

Hale, W:

Türk Dış Politikası 1774-2000, Çev. Petek Demir, İstanbul, Mozaik, 2003.

Hemingway, E.: Selected Articles and Dispatches of Four Decades. Edited İnönü, İsmet: by William White, New York, Charles Scribner's, 1967. Ismet Inönü'nün Hatıralarl, Büyük Zaferden Sonra Mudanya Mütarekesi ve Lozan Antlaşmast 1, İstanbul, Yenigün Haber Ajansı Basın ve Yayıncılık A.Ş, 1998.

Karacan, Ali Naci: $\quad$ Lozan, İstanbul, Nokta Yayınları, 2007.

Киреев, Николай Г.: $\quad$ История Турцุии. XX век, Москва, Крафт+ИВ РАН, 2007.[ Kireev Nikolay Grigorevich, İstoriya Turtsii. XX vek, Moskva, Kraft+IV RAN, 2007]

Ленин, Владимир И.: $\quad$ Полное Собрание Сочинений 45, (Mарт 1922Mapm 1923), Москва, Издательство Политической Литературы, 1970. [Lenin, Polnoye Sobraniye Sochineniy, 45, (Mart 1922- Mart 1923), Moskva, İzdatelstvo Politicheskoy Literaturı, 1970]

Meray, Seha:
Lozan Barış Konferansı Tutanaklar, Belgeler, Ankara, Ankara Üniversitesi Basımevi, 1969. 
Meyer, Mihail S.:

"Arşiv Belgeleri Işı̆̆ında Lozan Konferansı Sırasında Türk-Rus İlişkileri, (Turkish-Russian Relations During the Lausanne Conference With Archieve Documents)", Çev: Fatih Yapıcı, Akademik Bakış, Cilt: 3, Sayı: 5, 2009. Народный Комиссариат По Иностранным Делам. Годовой, Отчёт В 1923 Год Ко II Съезду Советов, Москва, 1924.[Narodn1y Komissariat Po İnostrannım Delam, Godovoy Otchet v 1923 god ko II Syezdu Sovetov, Moskva, 1924]

Нежинский, Л. Н., Игнатьев, А. В: $\quad$ Россия и Черноморские проливы (XVIII-XX столетия), Москва,Международные отношения, 1999. [Nejinskiy L.N, İgnatyev A.V., Rossiya i Chernomorskiye Prolivi (XVIII-XX stoletiya), Mejdunarodnıe Otnasheniya, Moskva, 1999]

Nihat, Erim:

Nur, Riza:

O’Connor, Timothi E.

Oran, Baskin:

Потемкин В. П:

Sonyel, Salahi:
Devletlerarası Hukuku ve Siyasi Tarih Metinleri Cilt: 1, Sevr Andlaşması, Ankara, Türk Tarih Kurumu Basımevi, 1953.

Hayatım Hatıratım 3.Cilt, İstanbul, Altındağ Yayınevi, 1967.

Г. В. Чичерин и Советская Внешняя Политика 1918-1930 г2, Пер. с англ. Общ. ред. Ю. С. Борисова; Послесл. И. М.Труша, Москва, Прогресс, 1991. [Timothi Edward O'Connor, G.V. Chicherin i Sovetskaya Vneshnyaya Politika 1918-1930 gg., Per. s Ang. Red. Y. S. Borisova, Moskva, Progress, 1991]

Türk Dış Politikası Kurtuluş Savaşından Bugüne Olgular, Belgeler, Yorumlar, Cilt 1(1919-1980), İstanbul, İletişim, 2009.

История дипломатии Том III Дипломатия в период подготовки Второй мировой войны 1919- 1939 22, Москва, ОГИЗ, Государственное Издательство Политической Литературы, 1945.[Potemkin, V.P., İstoriya Diplomatii, Tom III, Diplomatiya $\mathrm{v}$ Period Podgotovki Vtoroy Mirovoy Voynı, 1919-1939 gg.,OGIZ, Gosudarstvennoe İzdatelstvo Politicheskoy Literatur1, Moskva, 1945]

Gizli Belgelerle Lozan Konferansinın Perde Arkasi, Ankara, Türk Tarih Kurumu Yayınları, 2014. 
Şimşir, Bilal:

Yalçın, Durmuş:

Yerasimos, Stefanos:

Зуев, Федор Г.:
Lozan Telgrafları I, Ankara, Türk Tarih Kurumu Basımevi, 1990.

Türkiye Cumhuriyeti Tarihi, Ankara, Atatürk Araştırma Merkezi, 2004.

Kurtuluş Savaşı'nda Türk-Sovyet İlişsileri (1917 -1923), İstanbul, Boyut Yayınc1l1k, 2000.

История международных отношений и внешней политики СССР (1870-1957 г2.), Москва, ВПШ при ЦК КПСС, 1957.[ Zuev Fedor Grigorevich (red), İstoriya Mejdunarodnıkh Otnasheniy i Vneshney Politiki SSSR(1870-1915gg), Moskva,VPSH pri TSK KPSS, 1957]

\section{EKLER}

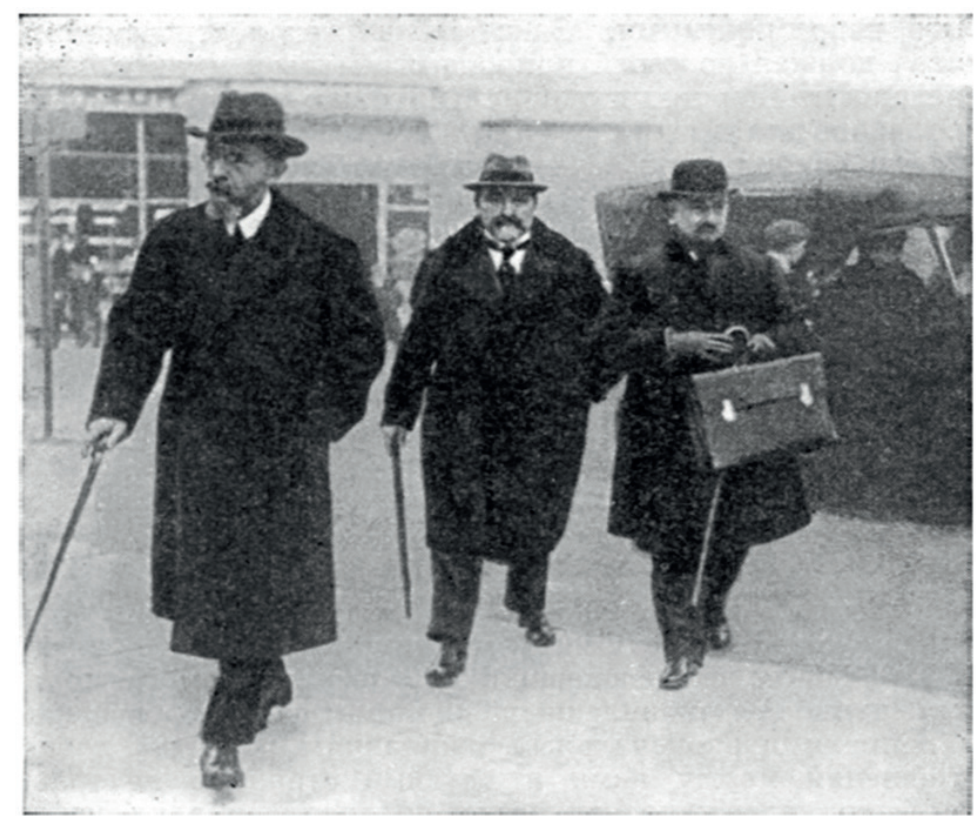

В. В. Боровский, Я. Х. Давтян и Г. В. Чичерин в Лозанне -1922 г.

Ek 1. V.V. Borovskiy, Y.H.Davtyan ve G.V. Chicherin Lozan'da, $1922 .{ }^{63}$

63 Чичерин, Георгий Васильевич, Статьи и Речи по Вопросам Международной Политики, Москва, Издательство Социально-Экономической Литературы, 1961, s. 249. 


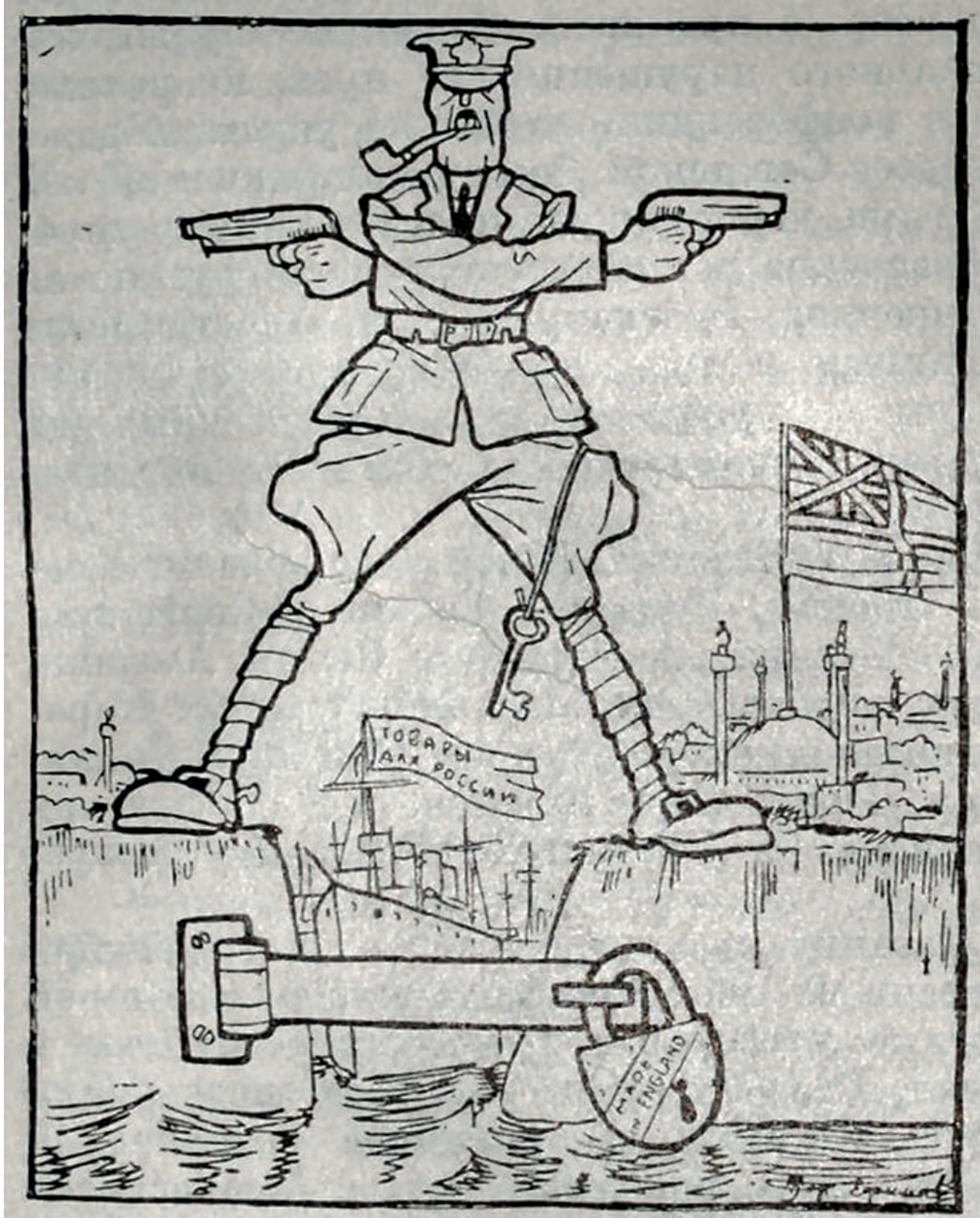

Ek 2. Boğazlar Meselesi üzerine İngiliz Projesi. B. Yefimov'un çizdiği karikatür, 1923. 